\title{
Yapatera y la historia del progreso según don Fernando Barranzuela, poeta y cumananero milenario
}

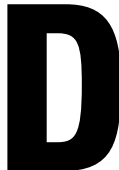
on Fernando Barranzuela ha escrito un libro que forma parte de un sueño, de que Yapatera alcance la libertad y la igualdad, es decir, la justicia para las gentes y ciudadanos/as de lo que ahora se llama centro poblado menor Yapatera, en la provincia de Morropón, departamento de Piura. En sus letras podemos encontrar un delicioso mensaje espiritual con mucha poesía y voluntad convencido de que Yapatera, esta vez acompañado de sus amigos y vecinos, asentado en un nuevo centro territorial llamado Cruzpampa-Yapatera, podrá alguna vez alcanzar el soñado progreso, es decir, un mundo más libre y más igualitario, expresando la esperanza y la aspiración de un colectivo humano multicolor. ${ }^{1}$

Yapatera, en el siglo XVIII, es el nombre universal de un territorio que administraba un corregidor y un cura-vicario desde la ciudad de San Miguel de Piura. En este tiempo histórico, esta toponimia se fortaleció bajo la forma de una hacienda estanciera y productora de cańa de azúcar, que explotaba la mano de obra esclava, los afluentes de agua y los densos bosques de algarrobo que marcaban sus fronteras con otras haciendas como Sol-Sol y Morropón al pie de las nacientes de la cordillera de los Andes.

$\mathrm{Al}$ interior de la gran hacienda de Yapatera, la población yunga y afrodescendiente laboraba la tierra y manejaba el ganado del dueño y sus propios hatos de manera dispersa; no existía un centro aglutinador, y las tierras y los bosques estaban ocupados por las parcelas de negros, zambos y mulatos, pero también por peones indígenas asalariados y familias de colonos y yanaconas mestizos, quienes labraban la tierra y las cosechas las compartían con el amo de la hacienda entregán-

1 Fernando Barranzuela Zevallos (2007). Historia de Yapatera. Colección Sec, Municipalidad Provincial de Piura, 175 pp. En 2012 publica otro libro titulado Cadenas Rotas. Historia de Yapatera. Aleph Impresiones S.R.L. Lima, Perú.
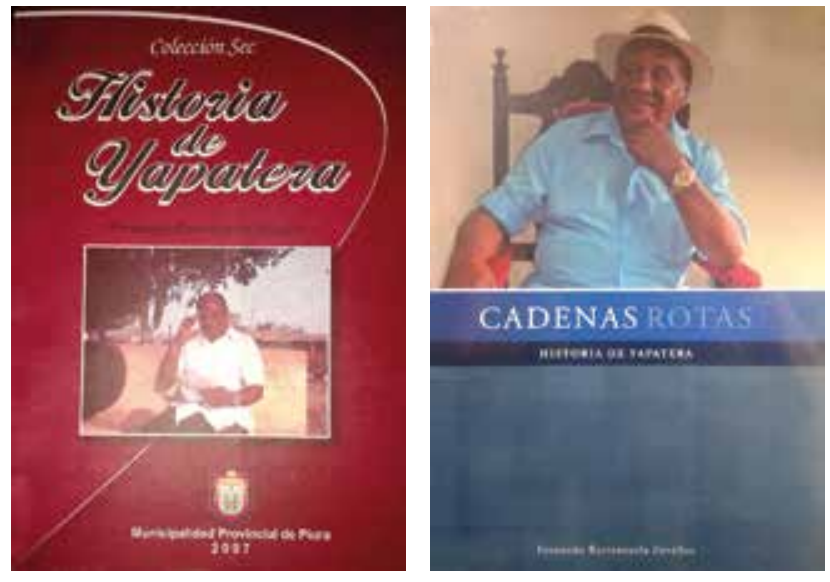

dole una renta anual en moneda plata, en productos y cuotas de fuerza de trabajo. Por aquí llegó el obispo Martínez de Compañón en 1783 con la misión de modernizar la vida de las gentes y profundizar la campaña de evangelización cristiana. Para este efecto ordenó el levantamiento de una pequeńa capilla y realizó un censo poblacional, además de conseguir arrancar un compromiso oral del dueño de la hacienda para que las gentes de múltiples colores se congregasen y recibiera la misa y sacramentos benditos. Martínez Compañòn difundió así la idea de una nueva vida urbana, hacía propaganda a la civilización borbónica hispana. Era un religioso convencido de que era posible cambiar el entorno material de los seres humanos para conquistar el espíritu y la ilusión de que la evangelización cristiana y la acumulación de la riqueza podían andar juntos armónicamente. Sin embargo, ya por el mundo circulaba la idea de que todo crecimiento económico generaba y expandía mucho más la desigualdad social. ${ }^{2}$

Don Fernando Barranzuela escribe un libro en la que nos demuestra y explica cómo esta idea del progreso en Yapatera fue interrumpido y se transitó de un

2 UDEP, 2008 Evangelización y vida eclesial en Piura. Siglos XVI y XVII. Facultad de Ciencias y Humanidades, Universidad de Piura. 
ciclo histórico de concentración y a la de expulsión poblacional de la gente multicolor fuera de sus fronteras territoriales, en una dimensión mayor y más profunda que en los siglos anteriores, después de la Segunda Guerra Mundial, cuando los propietarios de la empresa agrícola de Yapatera transitan del cultivo de la caña de azúcar a la producción del algodonero. Así vieron y sintieron como la idea de Keynes, de que el progreso era imparable, se derrumbaba implacablemente y se ingresaba a un tiempo de contracciones económica de paros laborales y desempleos masivos. La ironía de la historia se hizo presente en este microterritorio golpeando el mundo rural de Piura cuando justamente el capitalismo mundial ingresaba a sus años felices: 1945-1975.

El libro de don Fernando Barranzuela destaca porque junto a la preocupación de la crisis material lanza algunas tesis acerca del decrecimiento de la igualdad y a la mejora colectiva. Sostiene que con la Reforma Agraria crecen las desigualdades y se producen varias explosiones sociales pues la parcelación de la tierra impondrá con mayor fuerza el hiperindividualismo y la destrucción de las instituciones que representaban a la población de Yapatera y que les servía para mejorar sus condiciones de vida.

En su libro se señala como la ley de creación de la provincia de Morropón y la asignación de la categoría de capital provincial al pueblo de Chulucanas en 1936, provocará que el distrito de Yapatera y sus autoridades (1884-1936) pasen a ser invisibilizados y silenciados casi medio siglo. Esta vez, un nuevo grupo de poder se asienta en lo que fue un pequeño caserío (Chulucanas) de Yapatera, para entonces diferenciarse y convertirse en distrito y capital de la nueva provincia de Morropón. En verdad, este decreto fue un imprevisto golpe político a los dueños de la hacienda Yapatera, quienes más adelante, buscaron la modernización de la agricultura de la caña de azúcar y del algodonero, frente a otro grupo que vía la renta ganadera de carne y cueros como lo simbolizaba por ejemplo la negociación agrícola y ganadera Pabur.

La historia política de los dueños y de los trabajadores en Yapatera está todavía por trabajar; en el libro de Barranzuela se encuentra algunos chispazos, muy cortos pero deslumbrantes de lo que pensaban los dueńos y de la gente de las chacras, de la cooperativa y de los parceleros y peones asalariados; la reorientación de los tipos de cultivo tienen que ver con la política gubernamental y regional, los mangos y los limones no llegaron solos, por allí estuvo triunfante don Alan Garcìa y Alberto Fujimori difundiendo las bondades y el discurso del progreso del neoliberalismo actual.

En el marco metodológico se encuentran aplicaciones interesantes de una metodología de investigación. Se encuentra así, el despliegue de un intenso trabajo de "Gabinete" con los materiales de archivo, de bibliotecas, periódicos y revistas de la región de Piura. En esta sección destaca por ejemplo, la ubicación, consulta y publicación de los manuscritos más antiguos de Yapatera, como son las partidas de bautizo de Yapatera de 1794, y también las Actas del Consejo Distrital de Yapatera de 1884, una diversidad de documentos que se conservan en el Archivo Parroquial de la Diócesis de Chulucanas y en el Archivo del Concejo Provincial de Morropòn, Chulucanas.

Otro esfuerzo intenso es el recojo de la memoria histórica mediante el recurso de la oralidad, de la palabra y el testimonio que recopila recorriendo el variado paisaje de Yapatera, Morropòn, Chulucanas y Piura. Las personas entrevistadas son múltiples, de varias localidades vecinas y de gentes multicolores. La exposición de este mundo de la oralidad se registra en su esfuerzo de mostrar la dinámica expresiva de la belleza cultural de Yapatera anotando las actividades desplegadas por las mujeres y los sudores de los peones, labriegos y trabajadores del campo que están convencidos de los milagros y las bondades de su santo patrón San Sebastián (San Chabaco). En esta sección de la oralidad se despliega también la fuerza espiritual de Fernando Barranzulea incluyendo sus copas y cumanananas, soñando que la vida y la palabra son eternas y milenarias.

En buena cuenta, con la escritura y publicación de este libro, se tiene mucho más claro la historia de Yapatera, que en casi cinco siglos transitó de una categoría universal política-administrativa, a partido y doctrina de Yapatera, a la formación de una pequeña urbe bautizada en el siglo XXI con el nombre de Cruzpampa de Yapatera, un centro-bisagra urbano, de construcción de la identidad local y de su proyecto de organización distrital como bandera y sueño reivindicativo de su lucha por la justicia social y la construcción de una nueva patria multiétnica y multicultural en estos tiempos de globalización planetaria.

César Espinoza Claudio 